\title{
Studies on Integrated Nutrient Management in Hybrid Rice (Oryza sativa L.) under Old Alluvial Zone of West Bengal, India
}

\author{
Nakul Mandal ${ }^{1 *}$, Arun Kumar Barik ${ }^{1}$, Ashis Kumar Singha Roy ${ }^{2}$, Pritam Ghosh ${ }^{1}$ and Biswajit Saha ${ }^{1}$
}

${ }^{1}$ Dept. of Agronomy, Palli Siksha Bhavana (Institute of Agriculture), Visva-Bharati, Sriniketan, Birbhum, W.B. (731 236), India

${ }^{2}$ Dept. of Agronomy, Uttar Banga Krishi Viswavidyalaya, Pundibari, Cooch Behar, West Bengal (736 165), India

\section{Corresponding Author}

Nakul Mandal

e-mail:nakul_mandal2004@rediffmail.com

\author{
Article History \\ Article ID: AR1909 \\ Received in $30^{\text {th }}$ September, 2018 \\ Received in revised form $07^{\text {th }}$ December, 2018 \\ Accepted in final form $08^{\text {th }}$ December, 2018
}

\begin{abstract}
A field experiment was conducted during kharif seasons of 2014 and 2015 at Instructional Farm of Dakshin Dinajpur Krishi Vigyan Kendra, Uttar Banga Krishi Viswavidyalaya, Majhian, Patiram, Dakshin Dinajpur, West Bengal, India located at $25^{\circ} 31^{\prime} \mathrm{N}$ latitude and $88^{\circ} 76^{\prime} \mathrm{E}$ longitude and at an altitude of $15 \mathrm{~m}$ above mean sea level to study the effect of integrated nutrient management on growth attributes, yield attributes, yield and economics of hybrid rice (Oryza sativa L.). The experiment, consisted of ten treatments, was laid out in Randomised Block Design where each treatment was replicated thrice. The test crop was grown following recommended package of practices. Standard statistical methods were followed for analysing the experimental data. Integrated nutrient management in hybrid rice significantly influenced growth attributes, yield attributes, yield and economics of hybrid rice. Application of $75 \%$ recommended dose of nitrogen (RDN) from urea+25\% RDN from dhaincha green manure exhibited highest growth attributes, yield attributes, grain yield $\left(5.74 \mathrm{t} \mathrm{ha}^{-1}\right)$, straw yield $\left(6.59 \mathrm{t} \mathrm{ha} \mathrm{a}^{-1}\right)$, gross return ( $₹ 95175 \mathrm{ha}^{-1}$ ) and net return ( $₹ 52541 \mathrm{ha}^{-1}$ ) from hybrid rice. However, this was at par with the application of $100 \%$ RDN from urea followed by $75 \%$ RDN from urea+25\% RDN from mustard oil cake. The highest return per rupee investment was achieved from $100 \%$ RDN from urea (₹ 2.25) though this was similar with 75\% RDN from urea+25\% RDN from dhaincha green manure (₹ 2.23 ).
\end{abstract}

Keywords: Hybrid rice, integrated nutrient management, yield, economics

\section{Introduction}

Rice is one of the most important cereal crops in India. In India by 2025 population level may reach as high as 1500 million in our country and there is an urgent need to increase the food production to meet the growing demand. The country needs about $130 \mathrm{mt}$ of rice by 2025 to feed the ever growing population. India has the largest area ( $44.14 \mathrm{mha}$ ) among rice growing countries and stands second in production (106.65 $\mathrm{mt}$ ) with a productivity of $2,416 \mathrm{~kg} \mathrm{ha}^{-1}$ (Anonymous, 2017). In West Bengal, rice is grown in an area of 55.14 lakh ha with a production of 153.71 lakh tonnes and productivity of 2,788 $\mathrm{kg} \mathrm{ha}^{-1}$ (Anonymous, 2017). Further, there is an urgent need to produce $50 \%$ more rice by 2025 to feed ever growing population in India with the existing limited and decreasing resources. It is estimated that rice requirement of India by 2020 will be $118.93 \mathrm{mt}$. Rice supplies $20 \%$ and $31 \%$ of the total calories required by world and Indian population, respectively (Sahane et al., 2013). Meeting the targeted demands of rice is a challenging task. Decreasing in the soil fertility and increasing in water scarcity is becoming threat for rice cultivation. Hence, the technology which maintains the soil health and water scarcity and as well as economically beneficial needs to be developed.

Presently indiscriminate use of chemical fertilisers alone has led to environmental pollution and deterioration of soil health, so balanced use of nutrients through inorganic and organic source is prerequisite to sustain soil fertility and to provide maximum crop yield with optimum input level. Beneficial effect of conjunctive use of organic and inorganic nutrients in hybrid rice were also reported by Bhowmik and Nayak (2000) and Pandey et al. (2007). Ghosh et al. (2015) estimated that only $30-50 \%$ of applied nitrogen fertilisers and $45 \%$ of phosphorus fertilisers are used for crops. However, the efficiency of applied nutrient use may be enhanced by the combined use of organic and inorganic fertilisers.

Rice productivity is now at stagnant situation or declining in areas where $\mathrm{N}$-fertiliser application is very high; it has also raised the concerns about sustainability of monoculture rice. To achieve food security, hybrid rice can be one of the most feasible options to increase $15-20 \%$ of food production. The hybrid cultivars are more responsive to higher doses of nutrients and thereby the yield potentiality is all high. New 
hybrid varieties have come up with the growers but their package and practices in integrated nutrient management mode was lacking. The present investigation was therefore undertaken to study the effect of integrated nutrient management on growth, yield and economics of transplanted hybrid rice.

\section{Materials and Methods}

A field experiment was conducted during kharif seasons of 2014 and 2015 at Instructional Farm of Dakshin Dinajpur Krishi Vigyan Kendra, Uttar Banga Krishi Viswavidyalaya, Majhian, Patiram, Dakshin Dinajpur, West Bengal, India located at $25^{\circ} 31^{\prime} \mathrm{N}$ latitude and $88^{\circ} 76^{\prime} \mathrm{E}$ longitude and at an altitude of $15 \mathrm{~m}$ above mean sea level to study the effect of integrated nutrient management on hybrid rice (Oryza sativa L.). Prior to rice cultivation soil samples were collected at the depth of $30 \mathrm{~cm}$, dried and ground and passed through $40 \mathrm{~mm}$ sieve and analysed for physico-chemical properties following the standard methods. The soil of the experimental site was clay loam with $\mathrm{pH}$ (5.3) and medium in organic carbon (0.41\%). The initial status of available $\mathrm{N}$ (Macro Kjeldahl method, Jackson 1973), $\mathrm{P}_{2} \mathrm{O}_{5}$ (Olsen's method Jackson, 1973) and $\mathrm{K}_{2} \mathrm{O}$ (Flame photometric method, Jackson, 1973) of the experimental site was $258.7,24.4$ and $119.3 \mathrm{~kg} \mathrm{ha}^{-1}$, respectively measured by using standard methods (Jackson 1973). The experiment, consisted of ten treatments, was laid out in Randomised Block Design where each treatment was replicated thrice. The treatments were $100 \%$ RDN (120 kg N ha-1) from chemical fertiliser (urea) $\left(T_{1}\right), 75 \%$ RDN from chemical fertiliser+25\% RDN from Mustard Oilcake $\left(\mathrm{T}_{2}\right), 75 \%$ RDN from chemical fertiliser+25\% RDN from Dhaincha $\left(\mathrm{T}_{3}\right), 75 \%$ RDN from chemical fertiliser+25\% RDN from FYM $\left(\mathrm{T}_{4}\right), 50 \%$ RDN from chemical fertiliser+50\% RDN from Mustard Oilcake $\left(\mathrm{T}_{5}\right), 50 \%$ RDN from chemical fertiliser+50\% RDN from Dhaincha $\left(\mathrm{T}_{6}\right)$, $50 \%$ RDN from chemical fertiliser+50\% RDN from FYM $\left(\mathrm{T}_{7}\right)$, $25 \%$ RDN from chemical fertiliser+75\% RDN from Mustard Oilcake $\left(T_{8}\right), 25 \%$ RDN from chemical fertiliser+75\% RDN from Dhaincha $\left(T_{9}\right), 25 \%$ RDN from chemical fertiliser+75\% RDN from FYM $\left(T_{10}\right)$. The field was ploughed, levelled and laid out according to experimental scheme. The amount of nitrogen applied through urea. The amount of dhaincha and FYM was calculated as per the treatment on the basis of net plot area and incorporated to the soil 30 days before transplanting. The mustard oil cake was also calculated as per the treatment on the basis of net plot area and incorporated to the soil before final puddling, in which mustard oil cake was powdered before application so that the manure was spread uniformly. Among the chemical fertilisers (NPK) one fourth of total nitrogen, entire $\mathrm{P}_{2} \mathrm{O}_{5}$ and $\mathrm{K}_{2} \mathrm{O}$ was applied after draining out the standing water but before final puddling. Top dressing of the remaining nitrogen was done in two equal splits; one at active tillering stage and the other at panicle initiation stage. Hybrid rice variety 'ARISE 6444' with seedlings of 25 days old were transplanted in a shallow depth $(2-3 \mathrm{~cm})$ at a spacing of $20 \times 15 \mathrm{~cm}^{2} @ 1$ seedling hill ${ }^{-1}$ on July 22 and July 19 during the year 2014 and 2015, respectively. Observations were recorded for various growth attributes, yield attributes and yield. Standard statistical methods were followed for analysing the experimental data (Gomez and Gomez, 1984).

\section{Results and Discussion}

\subsection{Growth attributes}

Different growth attributes viz. plant height, tiller number, leaf area index, dry matter accumulation, crop growth rate and net assimilation rate were recorded, statistically analysed and tabulated (Table 1). Integrated nutrient management in hybrid rice did not show any significant difference of plant height among the treatments. However, taller plant $(112.85 \mathrm{~cm})$ of hybrid rice was recorded with application of $25 \%$ RDN from chemical fertiliser+75\% RDN from mustard oil cake and the lowest value $(107.32 \mathrm{~cm})$ was recorded in application of $50 \%$ RDN from chemical fertiliser+50\% RDN from FYM. Significantly highest number of tillers $\mathrm{m}^{-2}$ (457.65) was recorded with the application of $75 \%$ RDN from chemical fertiliser+25\% RDN from dhaincha green manuring from all other treatments except $\mathrm{T}_{2}$ (447.70) where 75\% RDN from chemical fertiliser+25\% RDN from mustard oil cake was applied. Integrated nutrient management played an important role on leaf area index (LAI) of kharif hybrid rice. The LAI varied significantly among the nutrient management practices. Pooled data of two years revealed that, the highest leaf area index (LAI) was recorded at 65 DAT (5.29) with application of $50 \%$ RDN from chemical fertiliser+50\% RDN from dhaincha green manure and lowest LAI (4.81) was recorded in 25\% RDN from chemical fertiliser+75\% RDN from FYM.

Nutrient management practices exerted positive and significant effect on dry matter accumulation of kharif hybrid rice. As per the pooled data the highest dry matter accumulation at 65 DAT $\left(715.83 \mathrm{~g} \mathrm{~m}^{-2}\right)$ was recorded in treatment with $100 \%$ RDN from chemical fertiliser only. However, the result was at par with application of $75 \%$ RDN from chemical fertiliser+25\% RDN from mustard oil cake (710.85 $\mathrm{g} \mathrm{m}^{-2}$ ) and 75\% RDN from chemical fertiliser $+25 \%$ RDN from dhaincha green manure $\left(712.96 \mathrm{~g} \mathrm{~m}^{-2}\right)$. Nutrient management practices exerted significant influence on the crop growth rate of hybrid rice at 50 to 65 DAT. Significantly highest crop growth rate (16.03 $\mathrm{g} \mathrm{m}^{-2}$ day $\left.^{-1}\right)$ was observed with application of $75 \%$ RDN from chemical fertiliser $+25 \%$ RDN from dhaincha green manure. Although the lowest value of crop growth rate (13.40 $\mathrm{g} \mathrm{m}^{-2}$ day $^{-1}$ ) was recorded with application of $25 \%$ RDN chemical fertiliser+75\% RDN from dhaincha green manure.

The net assimilation rate of hybrid rice was recorded from each plot at 50 to 65 DAT was analyzed statistically. Nutrient management practices showed significant effect on net assimilation rate of kharif hybrid rice. As per the pooled data of both years for the growth period 50 to 65 DAT the highest 
Table 1: Effect of Integrated Nutrient Management on growth attributes of hybrid rice during kharif season of 2014 and 2015 (pooled data)

\begin{tabular}{lcccccc}
\hline Treatments & $\begin{array}{c}\text { Plant height at } \\
\text { harvest }(\mathrm{cm})\end{array}$ & $\begin{array}{c}\text { No. of tiller } \mathrm{m}^{-2} \\
\text { area at 65 DAT }\end{array}$ & $\begin{array}{c}\text { LAl at 65 } \\
\text { DAT }\end{array}$ & $\begin{array}{c}\text { DMA }\left(\mathrm{g} \mathrm{m}^{-2}\right) \text { at } \\
65 \text { DAT }\end{array}$ & $\begin{array}{c}\text { CGR }\left(\mathrm{g} \mathrm{m}^{-2} \mathrm{day}^{-1}\right) \text { at } \\
\text { 50-65 DAT }\end{array}$ & $\begin{array}{c}\mathrm{NAR}_{\left(\mathrm{g} \mathrm{m}^{-2} \mathrm{day}^{-1}\right)} \\
\text { at 50-65 DAT }\end{array}$ \\
\hline $\mathrm{T}_{1}$ & 112.20 & 440.90 & 5.17 & 715.83 & 15.84 & 3.53 \\
$\mathrm{~T}_{2}$ & 109.01 & 447.70 & 5.17 & 710.85 & 15.99 & 3.34 \\
$\mathrm{~T}_{3}$ & 111.85 & 457.65 & 5.28 & 712.96 & 16.03 & 3.31 \\
$\mathrm{~T}_{4}$ & 109.85 & 432.95 & 4.86 & 680.36 & 15.95 & 3.57 \\
$\mathrm{~T}_{5}$ & 112.83 & 436.33 & 4.97 & 674.87 & 14.45 & 3.28 \\
$\mathrm{~T}_{6}$ & 111.52 & 441.40 & 5.29 & 683.16 & 15.07 & 3.06 \\
$\mathrm{~T}_{7}$ & 107.32 & 431.93 & 4.82 & 659.16 & 15.00 & 3.50 \\
$\mathrm{~T}_{8}$ & 112.85 & 426.30 & 5.03 & 639.05 & 14.10 & 3.25 \\
$\mathrm{~T}_{9}$ & 111.76 & 426.48 & 5.17 & 644.86 & 13.40 & 2.79 \\
$\mathrm{~T}_{10}$ & 108.89 & 423.18 & 4.81 & 639.68 & 14.24 & 3.35 \\
$\mathrm{SEm} \pm$ & 1.326 & 4.169 & 0.101 & 4.950 & 0.449 & 0.146 \\
$\mathrm{CD}(p=0.05)$ & $\mathrm{NS}$ & 11.973 & 0.290 & 14.216 & 1.428 & 0.419 \\
\hline
\end{tabular}

$\mathrm{T}_{1}: 100 \% \mathrm{RDN}\left(120 \mathrm{~kg} \mathrm{~N} \mathrm{ha}^{-1}\right.$ ) from chemical fertiliser; $\mathrm{T}_{2}: 75 \% \mathrm{RDN}$ from chemical fertiliser+25\% RDN from Mustard Oilcake; $\mathrm{T}_{3}: 75 \%$ RDN from chemical fertiliser+25\% RDN from Dhaincha; $\mathrm{T}_{4}: 75 \%$ RDN from chemical fertiliser+25\% RDN from $\mathrm{FYM}$; $\mathrm{T}_{5}: 50 \%$ RDN from chemical fertiliser+50\% RDN from Mustard Oilcake; $\mathrm{T}_{6}: 50 \%$ RDN from chemical fertiliser+50\% RDN from Dhaincha; $T_{7}: 50 \%$ RDN from chemical fertiliser+50\% RDN from FYM; $T_{8}: 25 \%$ RDN from chemical fertiliser+75\% RDN from Mustard Oilcake; $\mathrm{T}_{9}: 25 \%$ RDN from chemical fertiliser+75\% RDN from Dhaincha; $\mathrm{T}_{10}: 25 \% \mathrm{RDN}$ from chemical fertiliser $+75 \%$ RDN from FYM; RDN: Recommended dose of nitrogen; DAT: Days after transplanting; LAI: Leaf area index; DMA: Dry matter accumulation; CGR: Crop growth rate; NAR: Net assimilation rate; NS: Not significant

NAR recorded in $75 \%$ RDN through chemical fertiliser+25\% RDN through FYM application. However, the result was at par with all other treatments except treatment with application of $50 \%$ RDN from chemical fertiliser+50\% RDN from dhaincha (3.06 $\mathrm{g} \mathrm{m}^{-2} \mathrm{day}^{-1}$ ) and 25\% RDN from chemical fertiliser+75\% RDN from dhaincha green manure $\left(2.79 \mathrm{~g} \mathrm{~m}^{-2} \mathrm{day}^{-1}\right)$.

Increased leaf area index, dry matter accumulation and crop growth rate might be due to increasing the level of chemical fertiliser may be ascribed to the fact that rice plant grew better and accumulated more dry matter as compared to the higher doses of organic manure and the result was similar with the findings of Dass et al. (2009). From the research findings by Singh et al. (2017) it was concluded that growth attributes like plant height, tiller numbers, green leaf numbers, dry matter production and leaf area recorded highest value where $50 \%$ $\mathrm{RDF}+50 \% \mathrm{~N}$ through FYM was applied to rice.

\subsection{Yield attributes and yield}

The yield attributes like number of panicle $\mathrm{m}^{-2}$ area differ significantly due to integrated nutrient management in hybrid rice (Table 2). Number of panicle (437.93 $\mathrm{m}^{-2}$ area), grain yield $\left(5.74 \mathrm{t} \mathrm{ha}^{-1}\right)$ and straw yield $\left(6.59 \mathrm{t} \mathrm{ha}^{-1}\right)$ were highest with the application of $75 \%$ RDN from chemical fertiliser+25\% RDN from dhaincha green manure though this was at par with $100 \%$ RDN from chemical fertiliser followed by $75 \%$ RDN from chemical fertiliser+ $25 \%$ RDN from mustard oil cake considering the data obtained from both the years. Mohanty et al. (2013) reported that application of chemical fertiliser, FYM and bio-fertiliser produced significantly higher number of tillers and highest number of grains panicle ${ }^{-1}$ as compared to $100 \%$ recommended dose of fertiliser and control. The higher straw yield was observed with hybrid was due to more vegetative growth parameters like plant height, tillers hill-1 ${ }^{-1}$ dry matter accumulation. These results are in confirmation with Madhu Babu, 2007 and Shashibhushan et al., 2007. The maximum grain yield was obtained by Shah and Kumar 2014 with the integration of NPK $50 \%$ RDF+neem cake@2.5 t ha-1 + FYM @ $5 \mathrm{t} \mathrm{ha}^{-1}+$ azotobacter+PSB @ 5 $\mathrm{kg} \mathrm{ha}^{-1}$. There was no significant difference in number of filled grain panicle ${ }^{-1}$ was observed in the first year (2014) whereas, significantly highest value was recorded in the second year (2015) and also compiling two years data with the application of $75 \%$ RDN from chemical fertiliser+25\% RDN from dhaincha and the result was statistically at par with the application $100 \%$ chemical fertiliser, $75 \%$ RDN from chemical fertiliser+25\% RDN from mustard oil cake, 50\% RDN from chemical fertiliser+50\% RDN from mustard oil cake, 50\% RDN from chemical fertiliser+50\% RDN from dhaincha, $25 \%$ RDN from chemical fertiliser+75\% RDN from dhaincha. Singh et al. (2013) also reported that significantly more number of grains per panicle was recorded with the treatment $75 \%$ of recommended NPK through inorganic+FYM @ $10 \mathrm{tha}^{-1}+\mathrm{BGA}$ 
Table 2: Effect of Integrated Nutrient Management on yield components, yield and economics of hybrid rice during kharif season of 2014 and 2015 (pooled data)

\begin{tabular}{lcccccccccc}
\hline Treatments & $\begin{array}{c}\text { No. of } \\
\text { panicles } \\
\mathrm{m}^{-2}\end{array}$ & $\begin{array}{c}\text { No. of filled } \\
\text { grains } \\
\text { panicle }{ }^{-1}\end{array}$ & $\begin{array}{c}\text { Test } \\
\text { weight } \\
(\mathrm{g})\end{array}$ & $\begin{array}{c}\text { Grain } \\
\text { yield } \\
\left(\mathrm{t} \mathrm{ha}^{-1}\right)\end{array}$ & $\begin{array}{c}\text { Straw } \\
\text { yield } \\
\left(\mathrm{t} \mathrm{ha}^{-1}\right)\end{array}$ & $\begin{array}{c}\mathrm{HI} \\
(\%)\end{array}$ & $\begin{array}{c}\text { Cost of } \\
\text { cultivation } \\
\left(₹ \mathrm{~h} \mathrm{a}^{-1}\right)\end{array}$ & $\begin{array}{c}\text { Gross } \\
\text { return } \\
\left(₹ \mathrm{k} \mathrm{h}^{-1}\right)\end{array}$ & $\begin{array}{c}\text { Net } \\
\text { return } \\
\left(₹ \mathrm{ha}^{-1}\right)\end{array}$ & $\begin{array}{c}\text { Return per } \\
\text { rupee in- } \\
\text { vested (₹) }\end{array}$ \\
\hline $\mathrm{T}_{1}$ & 421.70 & 147.87 & 25.16 & 5.61 & 6.39 & 46.74 & 41378 & 92970 & 51592 & 2.25 \\
$\mathrm{~T}_{2}$ & 422.12 & 150.11 & 25.22 & 5.68 & 6.32 & 47.29 & 50464 & 94071 & 43607 & 1.87 \\
$\mathrm{~T}_{3}$ & 437.93 & 152.28 & 25.07 & 5.74 & 6.59 & 46.59 & 42634 & 95175 & 52541 & 2.23 \\
$\mathrm{~T}_{4}$ & 408.58 & 137.26 & 24.95 & 5.26 & 5.95 & 46.93 & 43409 & 87156 & 43747 & 2.01 \\
$\mathrm{~T}_{5}$ & 415.32 & 146.09 & 25.01 & 5.39 & 6.06 & 47.08 & 59550 & 89298 & 29748 & 1.50 \\
$\mathrm{~T}_{6}$ & 413.95 & 145.49 & 24.85 & 5.43 & 6.06 & 47.30 & 42390 & 90823 & 48433 & 2.14 \\
$\mathrm{~T}_{7}$ & 406.82 & 139.96 & 24.78 & 5.11 & 5.65 & 47.51 & 45440 & 84601 & 39160 & 1.86 \\
$\mathrm{~T}_{8}$ & 392.63 & 139.08 & 24.81 & 4.94 & 5.51 & 47.26 & 68637 & 81819 & 13182 & 1.20 \\
$\mathrm{~T}_{9}$ & 395.13 & 148.92 & 24.64 & 5.03 & 5.59 & 47.37 & 42372 & 83232 & 40860 & 1.97 \\
$\mathrm{~T}_{10}$ & 392.28 & 139.37 & 24.30 & 4.59 & 5.09 & 47.39 & 47472 & 76002 & 28530 & 1.60 \\
$\mathrm{SEm} \pm$ & 4.183 & 3.394 & 0.084 & 0.073 & 0.033 & - & - & 1164.53 & 1164.53 & 0.025 \\
$\mathrm{CD}(p=0.05)$ & 12.013 & 9.747 & 0.241 & 0.210 & 0.095 & - & - & 3344.32 & 3344.32 & 0.072 \\
\hline
\end{tabular}

Selling price of rice ₹ $15900 \mathrm{t}^{-1}$, straw ₹ $500 \mathrm{t}^{-1}$ (2014) and rice ₹ $16100 \mathrm{t}^{-1}$, straw ₹ $500 \mathrm{t}^{-1}$ (2015); Cost of Mustard oil cake ₹ $16 \mathrm{~kg}^{-1}$ (2014), ₹ $16.50 \mathrm{~kg}^{-1}$ (2015), FYM ₹ $0.50 \mathrm{~kg}^{-1}$ (2014 and 2015), Dhaincha ₹ $0.50 \mathrm{~kg}^{-1}$, Urea ₹ $7.20 \mathrm{~kg}^{-1}$, SSP ₹ $8.40 \mathrm{~kg}^{-1}$, MOP ₹ $13.00 \mathrm{~kg}^{-1}$, labour ₹ 220 manday $^{-1}$

@ $15 \mathrm{~kg} \mathrm{ha}^{-1}$ and the result was closely followed by the treatments $100 \%$ of recommended NPK through inorganic. Test weight was recorded significantly highest (25.22) with the application of $75 \%$ RDN from chemical fertiliser+25\% RDN from mustard oil cake and the result was statistically at with the application of $100 \%$ RDN from chemical fertiliser, $75 \%$ RDN from chemical fertiliser+25\% RDN from dhaincha, $75 \%$ RDN from chemical fertiliser+25\% RDN from FYM and $50 \%$ RDN from chemical fertiliser+50\% RDN from mustard oil cake. Yang et al. (2004) recorded that 1000-grain weight was increased by the application of chemical fertiliser along with organic manure. Sri Ranjitha et al. (2013) reported from his study that maximum grain and straw yield was found with the application of $50 \%$ RDN (through urea) $+50 \%$ RDN (organic) through vermicompost and was found to be significantly superior over the rest of the treatments followed by the treatment $100 \%$ RDN (through urea).

\subsection{Economics}

Statistically analysed pooled data of two years field experiment revealed that, the highest cost of cultivation was recorded in treatment $\mathrm{T}_{8}$ where $25 \% \mathrm{RDN}$ from chemical fertilizer+75\% RDN from mustard oil cake was applied ( $₹$ $68,637 \mathrm{ha}^{-1}$ ) followed by application of $50 \%$ RDN from chemical fertilizer+50\% RDN from mustard oil cake (₹ $59550 \mathrm{ha}^{-1}$ ). In the treatment of only chemical nitrogen application it was the lowest ( $₹ 41,378 \mathrm{ha}^{-1}$ ) cost of cultivation of rice. The result indicated that, combination of organic and inorganic nutrients became costlier than that of RDN from sole chemical fertilizer; it might be due to higher cost of organic manures such as mustard oil cake, FYM and Dhaincha.

Integrated nutrient management practices showed significant effect on gross return of kharif rice in both the years. As per the pooled data of 2014 and 2015 the highest gross return was recorded in $75 \%$ RDN from chemical fertilizer+25\% RDN from dhaincha green manuring ( $₹ 95175$ ha $^{-1}$ ) which was statistically at par with application of $100 \%$ RDN from chemical fertilizer ( ₹ 92970 ha $^{-1}$ ) and $75 \%$ RDN from chemical fertilizer $+25 \%$ RDN mustard oil cake ( $₹ 94071 \mathrm{ha}^{-1}$ ). Similar trend was recorded in net return of kharif hybrid rice. Where, significantly highest net return ( $₹ 52541 \mathrm{ha}^{-1}$ ) was estimated with $75 \%$ RDN from chemical fertiliser+25\% RDN from dhaincha green manure followed by application of $100 \%$ RDN from chemical fertiliser (₹ 51592). The lowest gross return and net return ₹ 76002 ha $^{-1}$ and ₹ $13182 \mathrm{ha}^{-1}$, respectively was observed with application of $25 \%$ RDN from chemical fertiliser+75\% RDN from FYM.

The highest return per rupee invested (₹ 2.25) was found in $100 \%$ RDN from chemical fertiliser. The result was similar with the findings of Borkar et al., 2008. However, this was at par with $75 \%$ RDN from chemical fertiliser+25\% RDN from dhaincha green manure ( $₹ 2.23$ ). Similar findings were also reported by Mathew et al. (2008). The lowest return per rupee investment ( $₹ 1.20$ ) was recorded with $25 \%$ RDN from chemical fertiliser+75\% RDN from mustard oil cake.

\section{Conclusion}

Application of $75 \%$ RDN from chemical fertiliser+25\% RDN from dhaincha green manure in hybrid rice was found best for obtaining profitable crop production. 


\section{References}

Agricultural Statistics at a Glance, 2017. Directorate of Economics and Statistics. Department of Agriculture, Cooperation \& Farmers Welfare. Ministry of Agriculture \& Farmers Welfare. Government of India. Available at http:// eands.dacnet.nic.in

Bhowmik, N., Nayak, R.L., 2000. Response of hybrid rice varieties to nitrogen, phosphorus and potassium fertilisers during dry season in West Bengal, Indian Journal of Agronomy 45(2), 323-326.

Dass, A., Sudhishri, S., Lenka, N.K., 2009. Integrated nutrient management for upland rice in Eastern Ghats of Orissa. Oryza 46(3), 220-226.

Directorate of Economics and Statistics, Ministry of Agriculture, Government of India. 2013-14. www. indiastat.com.

Ghosh, B.N., Singh, R.J., Mishra, P.K., 2015. Soil and input management options for increasing nutrient use efficiency. In: Nutrient Use Efficiency: from Basics to Advances, (A. Rakshit et al. (Eds.), DOI 10.1007/978-81322-2169-22, Springer, India.

Gomez, K.A., Gomez, A.A., 1984. Statistical Procedures for Agricultural Research. John Wiley and Sons, Singapore.

Jackson, M.L., 1973. Soil Chemical Analysis. Prentice Hall of India Pvt. Ltd., New Delhi, India.

Madhu Babu, K., 2007. Performance of SRI over conventional method under ore well irrigation system and perception of farmers in Nalgonda district of Andhra Pradesh. In: SRI India 2007 Second National Symposium on System of Rice Intensification (SRI) in India-Progress and Prospects. Papers and Extended Summaries, $3-5^{\text {th }}$ October, Agartala, Tripura, India, 162-165.

Mathew, J., Kuruvilla, V., Pillai, G.R., 2008. Integrated nutrient management in sandy loam soil on the productivity and economics of rice. Oryza 30, 26-29.

Mohanty, M., Nanda, S.S., Barik, A.K., 2013. Effect of integrated nutrient management on growth, yield and nutrient uptake and economics of wet season rice (Oryza sativa) in Odisha. Indian Journal of Agricultural Sciences 83(6), 599-604.

Pandey, N., Verma, A.K., Anurag and Tripathy, R.S., 2007. Integrated nutrient management in transplanted hybrid rice. Indian Journal of Agronomy 52(1), 323-326.

Sahane, A.A., Singh, Y.B., 2013. Cyanobacteria: A green nitrogen for rice. Indian Farming 63(6), 3-6.

Shah, A.R., Kumar, S., 2014. Effect of integrated nutrient management on vegetative growth and yield of transplanted hybrid rice (Oryza sativa L.) crop, International Journal of Agriculture and Crop Sciences 7(11), 863-869.

Shashibhushan, V., Satyanarayan, A., Goud, V., 2007. Impact of SRI on Rice Farmers. In: SRI India 2007 Second National Symposium on System of Rice Intensification (SRI) in India-Progress and Prospects. Papers and Extended Summaries, $3-5^{\text {th }}$ October, Agartala, Tripura, India, 180-183.

Singh, R.K., Kumar, J.S.A., Kaleem, M., 2013. Influence of integrated nutrient management practices on yield and economics of hybrid rice (Oryza sativa L.). International Journal of Agricultural Science 9(2), 733-735.

Singh, S., Bohra, J.S., Singh, Y.V., Upadhyay, A.K., Verma, S.S., Mishra, P.K., Raghuveer, M., 2017. Effect of integrated nutrient management on growth and development stages of rice under Rice-Wheat Ecosystem. International Journal of Current Microbiology and Applied Science 6(7), 2032-2042.

Sri Ranjitha, P., Mahender Kumar, R., Jayasree, G., 2013. Evaluation of rice (Oryza sativa L.) varieties in relation to different nutrient management practices for yield, nutrient uptake and economics in SRI, Annals of Biological Research 4(10), 25-28.

Yang, C.M., Yang, L., Yang, Y., Ouyang, Z., 2004. Rice root growth and nutrient uptake as influenced by organic manure in continuously and alternately flooded paddy soils. Agricultural Water Management 70(1), 67-81. 